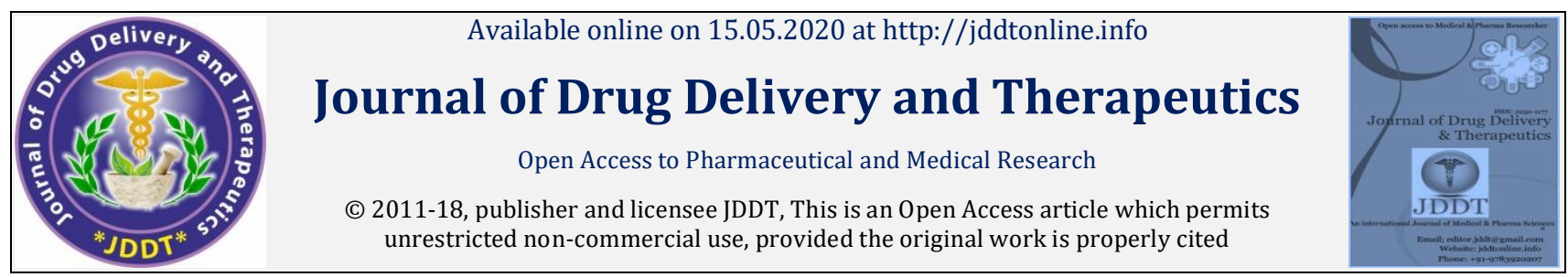

Open $\odot$ Access

Review Article

\title{
A review on various aspect of COVID-19
}

\author{
*Sherpa Lakpa Sangay \\ School of Pharmacy, Abhilashi University, Chail Chowk, Mandi, H.P., India
}

\begin{abstract}
This review is virtually focused on the current pandemic (Covid-19), its pathogenesis and recent treatment available till date .As ,we know that covid-19, caused by SARS-COV 2 is highly mutating and transmissible virus which has put a new challange for development of vaccines and drugs to researchers worldwide. Among Corona virus, SARS-COV 2 is a $7^{\text {th }}$ corona virus which is highly transmissible from human to human and no vaccines are available till date, due to this it has become a global threat for human being. It is believed to be zoonotic disease but no clean evidence of it main source has been known
\end{abstract}

Keywords: SARS-COV 2, Pandemic, Pneumonia, respiratory system.

Article Info: Received 07 April 2020; Review Completed 28 April 2020; Accepted 03 May 2020; Available online 15 May 2020

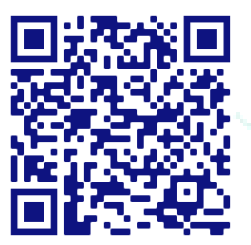

\section{Cite this article as:}

Sherpa LS, A review on various aspect of COVID-19, Journal of Drug Delivery and Therapeutics. 2020; 10(3):300-303 http://dx.doi.org/10.22270/jddt.v10i3.4031

*Address for Correspondence:

Sherpa Lakpa Sangay, School of Pharmacy, Abhilashi University, Chail Chowk, Mandi, H.P., India

\section{Background}

The First case of COVID-19 was reported from Wuhan, Hubei province, China in late December 2019, where large number of patient was admitted to hospital due to pneumonia. Later on the causative agent for such a mass scale of pneumonia was found to be a viral disease caused by SARS-COV 2, similar to SARS-COV 1 but highly transmissible and mutagenic.[1] Some scientist believe that it is zoonotic disease,which spread from bats as genome analysis of novel coronavirus sequences revealed that the complete genome sequence recognition rates of SARS-CoV 2 and bat SARS coronavirus (SARSr-CoV-RaTG13) were $79.5 \%$ and $96 \%$ respectively.[2] Like SARS and MERS causing corona virus, COVID-19 causing virus also belong to same class of virus prevalent in nature- $\beta$ corona virus. WHO declared COVID-19 outbreak a public Health Emergency of International Concern on 30/Jan/2020 and a pandemic on 11 march 2020.[3]

\section{Introduction}

COVID-19 was first identified in 2019 at Wuhan and spread globally resulting in 2019-2020 global pandemic. COVID-19 is caused by a $\beta$-corona virus (SARS COV-2) which is highly transmissible and mutagenic despite of low mortality rate. Similar to SARS and MERS disease, the patient infected with COVID-19 exhibit viral pneumonia, including fever, difficulty breathing, and bilateral lung infiltration in the most severe cases.[4] The mortality of the emerging coronavirus of 2019 seems mainly to be caused by acute respiratory distress syndrome (ARDS) [5] which may be associated with comorbidities and followed by multiple organ failure leading to death [6].

Till date researcher has found 7 corona viruses, including SARS-Cov 2, they are HCoV-229E, HCoV-NL63, HCoV-OC43, HCoV-HKU1, SARS-CoV, and MERS-CoV3. HCoV-229E and HCoV-NL63 belong to the alpha coronavirus, and the others include SARS-CoV-2 belong to beta coronavirus.[7] SARS$\mathrm{CoV}$ and MERS-CoV were considered highly pathogenic that transmitted from bats to human via intermediate host palm civets and dromedary camels, respectively.[8,9]

\section{Gastrointestinal aspects of covid-19}

It has been found that virus of COVID-19 has high affinity to angiotenson converting enzyme 2 receptor (ACE-2) which are also found in epithelial cell of gastrointestinal tract.[10] Corona virus has potential to bind to ACE 2 receptor present in epithelial cell of GIT to develop symptoms like nausea, vomiting, diarrhoea and abdominal pain. Studies has identified the presence of corona virus in anal and rectum swab and stool specimen of infected person even after the clearance of virus from upper respiratory tracts.[11]

Typically, COVID-19 is a respiratory illness but some patient was reported of nausea, vomiting, diarrhoea and abdominal pain. In USA, a 35 year old patient infected with corona virus has 2 days history of nausea and vomiting, on admit to hospital, patient has suffered from diarrhoea and abdominal 
discomfort from the $2^{\text {nd }}$ day. On day 7, the SARS-CoV-2 RNA was detected in stool of the patient by reverse-transcriptase polymerase-chain-reaction (RT-PCR).[12]

In early epidemic, a large study was done, in which data was collected from 1,099 patients from 552 hospital of China. It reported nausea or vomiting in $55(5.0 \%)$ and diarrhoea in 42 (3.8\%) patients.[13] Several other group have reported frequencies of diarrhoea ranging $2.0-10.1 \%$, and nausea and vomiting ranging 1.0-10.1\%.[14] In Wuhan, a group of 140 COVID-19 patient was studied were $39.6 \%$ was having gastrointestinal symptoms, including nausea $17 \%$, diarrhoea $12.9 \%$ and vomiting $5 \%$. Similarly the rate of diarrhoea in a group of 73 patient was found to be $35.6 \% \cdot[15]$

Although at a lower frequency compared to SARS, some Covid-19 patients do develop gastrointestinal symptoms during their disease course. This suggests that there is possibility for a tropism of SARS Cov 2 in gastrointestinal tract. Genome sequences showed that SARS-CoV-2 shared $79.6 \%$ sequence identity to SARS-CoV, both encoding and expressing the spike (S) glycoprotein that could bind to the entry receptor ACE2 to enter human cells. The receptor binding domain on SARS-CoV-2 could bind to human ACE2 with high affinity, correlating with the efficient spread of the virus among humans.[16]

\section{Current clinical features and obstetrical outcomes of pregnant women with COVID-19 [17]}

In the epicentre of pandemic in China, Tingji Hospital of Tingji Medical College, Huazhong University, Wuhan, 9 cases of COVID-19 infected pregnant women was reported whose SARS-CoV-2 positivity was confirmed by rt-PCR. The mother age varied from 26 to 40 years old. None of them has any pre-existing chronic condition like diabetes, hypertension or cardiovascular disease. 3 women had co-morbid conditions that developed during their pregnancy - influenza (Case 1), gestational hypertension occurring since 27 weeks gestation (Case 3), and preeclampsia developing at 31 weeks gestation (Case 4). Seven women were febrile upon admission; additional findings included cough (4/9), myalgia (3/9), sore throat (2/9) malaise (2/9), gastrointestinal symptoms (1/9) and shortness of breath (1/9). Laboratory test report include C-reactive protein (6/9), lymphopenia (5/9), and increased alanine aminotransferase 129 (ALT) and aspartate amino transferase (AST)(3/9). Lungs with patchy groundglass shadows was been demonstrated by 8 of the 9 women. None of the women develop pneumonia and there was no maternal death.

All women had a normal birth with no infection of COVID-19 in a baby. 6 cases was tested for SARS CoV-2 virus, sample of amniotic fluid, breast milk, umbilical cord blood and neonatal throat swab was evaluated-all tests was negative.

\section{Liver injury in Covid-19 patients}

It has been observed that COVID-19 can cause liver injury, while mechanism of action for injury is still not understood. It may be due to the direct virus infection at hepatocytes, immune-related injury or drug hepatotoxicity. [18] Most of the injuries are mild, although severe damage may occur. In case of severe condition of COVID-19 patient liver injury was reported. In group of 99 patient of COVID-19 in Wuhan 43 patients had raised ALT or AST; one patient with critical Covid-19 had severe hepatitis with serum ALT increased up to $7590 \mathrm{U} / \mathrm{L}$.[19] In a group of 56 Covid-19 patients, gammaglutamyl transferase (GGT) was elevated in 54\% of the patients.[20]

\section{Respiratory system in COVID-19}

Similar to SARS-COV-1, SARS COV-2 also invade the human body through ACE2.ACE 2 is an enzyme highly expressed in the outer membrane of cells of lungs, arteries, heart, kidney and intestine. A human version of enzyme is known as hACE2. ACE2 is an essential part of the RAS, and it has extensive vascular and organ protection functions in hypertension, diabetes, cardiovascular disease, and ARDS. [21] The tropism of SARS COV-2 in ACE 2 receptor is due to the s-protein spike present in the outer membrane of virus. The most severe form of lungs injury is acute respiratory distress syndrome(ARDS) which is characterize by increased pulmonary vascular permeability and pulmonary edema. [22]Patient of COVID-19 rarely suffered from upper respiratory symptoms (such as snot, sneezing and sore throat) indicating that virus primarily effects lower respiratory tracts. [23]

On 2 Jan 2020, at the epicentre of COVID-19,Wuhan,China .41 covid-19 infected patient are admitted,most of the infected person were man (21 out of 41 ), less than half had a underlying disease including diabetes (8), hypertension (6) and cardiovascular disease (6). Median age was 49 years. Common symptoms at onset of illness were fever ( 40 of 41 patients), cough (31), and myalgia or fatigue (18), less common symptoms were sputum production (11 of 39), headache (3 of 38), haemoptysis ( 2 of 39), and diarrhoea (1 of 38). Dyspnoea developed in 22 of 40 patients (median time from illness onset to dyspnoea 8.0 days). [24]

\section{Western treatment of COVID-19}

Covid-19 a viral disease which is caused by SARS COV-2 virus is a new strain of corona-virus that was identified at late December 2019 in Wuhan, China. Since, it is a new virus known by mankind there is no vaccines and special treatment available for it so far. Development of vaccines and drugs in traditional method is a long and tedious process. Therefore, there is another option in which a systematic and large-scale screening of existing drugs is done to see whether they have activity against the COVID-19. [25]

An anti-HIV drug kaletra, which is composed of two protease inhibitor, Ritonavir and Liponavir was a recommended by the National Health Commission of the People's Republic of China for the treatment of Wuhan pneumonia. [26] It has reported that $\beta$-coronavirus viral loads of a COVID-19 patient in Korea significantly decreased after lopinavir/ritonavir (Kaletra ${ }^{\circledR}$, AbbVie, North Chicago, IL, USA) treatment.[27] Recently, Remdesivir an antiviral drug has also gain some popularity due to good antiviral property against a wide array of RNA virus. It has been reported that patient treated with remdesivir against COVID-19 has achieved good result. [28] Recently China National Center for Biotechnology Development has suggested that chloroquine in one of three drugs which have a promising action in symptomatic treatment of COVID-19, it has been reported that patient treated with chloroquine was recovered within short duration and symptoms of fever was subsided faster and improvement in lungs computed tomography (CT) images with no severe adverse effect as compared to controlled group. [29] As a result, choroquine is used as frontline drugs for the treatment of COVID-19 worldwide.

\section{Chinese medical treatment}

The Chinese medicine has also played a major role to controlling and recovery from COVID-19 in China. In China local government and medical institution has published 
many medical prescription. The Novel Coronavirus Pneumonia Diagnosis and Treatment Plan (6 $6^{\text {th }}$ trial version) suggested use of clearing lung and detoxification decoction in the clinical treatment. Additionally, clinicians combined Chinese and Western medicine treatment including lopinavir/ritonavir (Kaletra $\left.{ }^{\circledR}\right)$, arbidol, and Shufeng Jiedu Capsule (SFJDC, a traditional Chinese medicine) and gained significant improvement in pneumonia associated symptoms in Shanghai Public Health Clinical Center, China. [30]

Table 1: Common and potent antiviral drugs. [31]

\begin{tabular}{|c|c|c|c|c|}
\hline Status & Drug & Mode of action & Anti-infective mechanism & Target disease \\
\hline Approved & $\begin{array}{l}\text { Lopinavir/ } \\
\text { Ritonavir }\end{array}$ & Protease inhibitors & $\begin{array}{l}\text { Inhibiting HIV-1 protease for } \\
\text { protein cleavage, } \\
\text { resulting in non-infectious, } \\
\text { immature viral particles }\end{array}$ & HIV/AIDS, SARS, MERS \\
\hline Experimental & $\begin{array}{l}\text { Remdesivir } \\
\text { (GS-5734) }\end{array}$ & $\begin{array}{l}\text { Nucleotide analogue } \\
\text { prodrug }\end{array}$ & Interfering with virus post-entry & Ebola, SARS, MERS \\
\hline $\begin{array}{l}\text { Approved, } \\
\text { Investigational, } \\
\text { Vet approved }\end{array}$ & Chloroquine & 9-aminoquinolin & $\begin{array}{l}\text { Increasing endosomal } \mathrm{pH} \text {, } \\
\text { immunomodulating, } \\
\text { autophagy inhibitors }\end{array}$ & $\begin{array}{l}\text { Malaria, autoimmune } \\
\text { disease }\end{array}$ \\
\hline Approved & Oseltamivir & $\begin{array}{l}\text { Neuraminidase } \\
\text { inhibitor }\end{array}$ & $\begin{array}{l}\text { Inhibiting the activity of the viral } \\
\text { neuraminidase } \\
\text { enzyme, preventing budding from } \\
\text { the host cell, viral replication, and } \\
\text { infectivity }\end{array}$ & Influenza viruses A \\
\hline $\begin{array}{l}\text { Approved, } \\
\text { Investigational }\end{array}$ & Ganciclovir & Nucleoside analogue & $\begin{array}{l}\text { Potent inhibitor of the Herpes } \\
\text { virus family } \\
\text { including cytomegalovirus }\end{array}$ & $\begin{array}{l}\text { AIDS-associated } \\
\text { cytomegalovirus } \\
\text { infections }\end{array}$ \\
\hline
\end{tabular}

HIV (Human Immunodeficiency Virus). AIDS (Acquired immunodeficiency syndrome) SARS (Severe acute respiratory symptoms) MERS (Middle east respiratory symptoms)

\section{Prevention of COVID-19}

Vaccines for a COVID-19 are under clinical trials, which are going to prepared within 18 month as per director general of WHO, Dr.Tedros. The clinical treatment for COVID-19 until now is palliative and supportive treatment. Therefore development of vaccines and drugs is very important As COVID-19 is caused by RNA virus. RNA virus related vaccines, including measles, polio, encephalitis $B$ virus and influenza virus, could be the most promising alternatives. And interpersonal transmission of the virus could be prevented by immunizing health care workers and noninfected population. [32]

The present principles on prevention of COVID-19 are to tonify body energy to protect outside body, dispel wind, dissipate heat, and dissipate dampness with aromatic agent. The six most commonly used Chinese herbal medicines are astragalus, liquorice, fangfeng, baizhu and honeysuckle. However, the decoction is not suitable for long-term use, and the best period is one week only. [33]

COVID-19 may cause respiratory symptom. Therefore vitamin $C$ can be used to prevent it. Patient with pre-existing health condition (such diabetes, hypertension, heart disease etc.) old age and children are more susceptible for infection due to the weak immune system. [34] COVID-19 infection can be controlled by choosing healthy lifestyle and maintenance personnel hygiene, taking supplementary nutrient such as vitamin $C$ could help to boost up immune system. For individuals, taking protective measures using mask, avoiding social gathering, maintaining social distance, washing and sanitizing hand frequently, and avoiding touching mouth, eyes, wounds with unwashed hand can prevent the spread of infection. [35].

\section{Conclusion}

COVID-19 has become a pandemic of 2019-20. This disease has become a global threat as no vaccines and drug has been developed so far. This disease has infected millions of people worldwide and killed thousands of people globally and numbers are increasing daily. COVID-19 is highly transmissible from human to human, so to control the spread of disease many countries are under lockdown including India. For current situation, the best way to control the spread this infection is maintenance of social hygiene and lockdown. The disease has brought a global economic slowdown, due to which, environment has got a chance to revive itself. Major river of India are cleansing itself, visibility has increased, and ozone layer has recovered completely.

Many pharmaceutical industries all over the world are doing their best to develop a vaccines and drug against COVID-19. Many techniques like plasma therapy; use of hydroxychloroquine has shown good result in controlling the current pandemic. 


\section{References}

1. Wang, L., Wang, Y., Ye, D., \& Liu, Q. A review of the 2019 Novel Coronavirus (COVID-19) based on current evidence. International Journal of Antimicrobial Agents, 105948: 2019. doi:10.1016/j.ijantimicag. 2020 .105948

2. Chen N, Zhou M, Dong X, Qu J, Gong F, Han Y, et al. Epidemiological and clinical characteristics of 99 cases of 2019 novel coronavirus pneumonia in Wuhan, China: a descriptive study. Lancet. 2020.

3. Liu Y, Gayle AA, Wilder-Smith A, Rocklov J. The reproductive number of COVID-19 is higher compared to SARS coronavirus. J Travel Med. 2020.

4. Wuhan Municipal Health Commision. Wuhan Municipal Health and Health Commission's Briefing on the Current Pneumonia Epidemic Situation in Our City. Available online http://wjw.wuhan.gov.cn/front/web/ show Detail/2019123108989

5. Zaki, A.M., et al., Isolation of a novel coronavirus from a man with pneumonia in Saudi Arabia. New England Journal of Medicine, 2012; 367(19):1814-1820

6. Zhou, P., et al., Discovery of a novel coronavirus associated with the recent pneumonia outbreak in humans and its potential bat origin. Biorxiv, 2020.

7 .Tang Q, Song Y, Shi M, Cheng Y, Zhang W, Xia XQ. Inferring the hosts of coronavirus using dual statistical models based on nucleotide composition. Sci Rep 2015; 5:17155

8. Guan Y, Zheng BJ, He YQ, et al. Isolation and characterization of viruses related to the SARS coronavirus from animals in southern China. Science 2003; 302(5643):276-278

9. Drosten C, Kellam P, Memish Z A. Evidence for camel-to-human transmission of MERS coronavirus. N Engl J Med. 2014 371(14):1359-1360

10. Xiao F, Tang M, Zheng X, Liu Y, Li X, Shan H. Evidence for gastrointestinal infection of SARS-CoV-2. Gastroenterology. 2020.

11. Zhang W, Du RH, Li B, et al. Molecular and serological investigation of 2019-nCoV infected patients: implication of multiple shedding routes. Emerg Microbes Infect. 2020; 9:386-9.

12. Holshue ML, DeBolt C, Lindquist S, et al. First Case of 2019 Novel Coronavirus in the United States. N Engl J Med. 2020; 382: 929 36.

13. Guan WJ, Ni ZY, Hu Y, et al. Clinical Characteristics of Coronavirus Disease 2019 in China. N Engl J Med. 2020.

14. Chen N, Zhou M, Dong X, et al. Epidemiological and clinical characteristics of 99 cases of 2019 novel coronavirus pneumonia in Wuhan, China: a descriptive study. Lancet. 2020; 395: 507-13.

15. Xiao F, Tang M, Zheng X, Liu Y, Li X, Shan H. Evidence for gastrointestinal infection of SARS-CoV-2. Gastroenterology. 2020.

16. Wrapp D, Wang N, Corbett KS, et al. Cryo-EM structure of the 2019-nCoV spike in the prefusion conformation. Science. 2020; 367:1260-3.

17. Schwartz, D. A. (2020). An Analysis of 38 Pregnant Women with COVID-19, Their Newborn Infants, and Maternal-Fetal Transmission of SARS-CoV-2: Maternal Coronavirus Infections and Pregnancy Outcomes. Archives of Pathology \& Laboratory Medicine. doi:10.5858/arpa.2020-0901-

18. Xu L, Liu J, Lu M, Yang D, Zheng X. Liver injury during highly pathogenic human coronavirus infections. Liver Int. 2020.
19. Chen N, Zhou M, Dong $X$, et al. Epidemiological and clinical characteristics of 99 cases of 2019 novel coronavirus pneumonia in Wuhan, China: a descriptive study. Lancet. 2020; 395: 507-13

20. Wong, S. H., Lui, R. N., \& Sung, J. J. Covid-19 and the Digestive System. Journal of Gastroenterology and Hepatology. 2020. doi:10.1111/jgh.15047

21. Cheng, H., Wang, Y., \& Wang, G.Q. Organ-protective Effect of Angiotensin-converting Enzyme 2 and its Effect on the Prognosis of COVID-19.Journal of Medical Virology. 2020 doi:10.1002/jmv.25785

22. Huang, C., Wang, Y., Li, X., et al. (2020). Clinical features of patients infected with 2019 novel coronavirus in Wuhan, China. The Lancet.doi:10.1016/s0140-6736 (20)30183-5

23. Imai $Y$, Kuba K, et al. Angiotensin-converting enzyme 2 protects from severe acute lung failure. Nature 2005; 436: 112-116. DOI: $10.1038 /$ nature 03712

24. Huang $C$ et. al. Clinical features of patients infected with 2019 novel coronavirus in Wuhan, China Published on 2020.Doi: org/10.1016/ S0140-6736(20)30251-8

25. Li, J.-Y., You, Z et. al. .The epidemic of 2019-novel-coronavirus (2019-nCoV) pneumonia and insights for emerging infectious diseases in the future. Microbes and Infection: 2020. doi: 10.1016/j.micinf.2020. 02.002

26. Wang ML CR, Zhang L.k, Yang XL, Liu J, Xu MY, et al. Remdesivir and chloroquine effectively inhibit the recently emerged novel coronavirus (2019-nCoV) in vitro. Cell Res 2020.

27. Lim J, Jeon S, Shin HY, Kim MJ, Seong YM, Lee WJ, et al. Case of the index patient who caused tertiary transmission of COVID-19 infection in Korea: the application of lopinavir/ritonavir for the treatment of COVID-19 infected pneumonia monitored by quantitative RT-PCR. J Korean Med Sci. 2020; 35(6):e79.

28. Holshue ML, DeBolt C, Lindquist S, Lofy KH, Wiesman J, Bruce $\mathrm{H}$, et al. First Case of 2019 Novel Coronavirus in the United States. The New England journal of medicine. 2020.

29. Gao J, Tian Z, Yang X. Breakthrough: chloroquine phosphate has shown apparent efficacy in treatment of COVID-19 associated pneumonia in clinical studies. Biosci Trends 2020 Feb doi:10.5582/bst.2020.01047

30. Wang Z, Chen X, Lu Y, Chen F, Zhang W. Clinical characteristics and therapeutic procedure for four cases with 2019 novel corona virus pneumonia receiving combined Chinese and Western medicine treatment. Biosci trend.

31. Guo, Y.-R., Cao, Q.-D., Hong, Z.-S., Tan, Y.-Y., Chen, S.-D., Jin, H.-J., Yan, Y. (2020).The origin, transmission and clinical therapies on coronavirus disease 2019 (COVID-19) outbreak - an update on the status. Military Medical Research 7(1).doi:10.1186/s40779020-00240-0

32. Zhang L, Liu Y. Potential Interventions for Novel Coronavirus in China: A Systematic Review. Journal of medical virology. 2020

33. Luo H, Tang QL, Shang YX, Liang SB, Yang M, Robinson N, et al. Can Chinese Medicine Be Used for Prevention of Corona Virus Disease 2019 (COVID-19) A Review of Historical Classics, Research Evidence and Current Prevention Programs. Chin J Integr Med. 2020.

34. Liang W, Guan W, Chen R, Wang W, Li J, Xu K, et al. Cancer patients in SARS-CoV-2 infection: a nationwide analysis in China. Lancet Oncol. 2020

35. Guan W-j, Ni Z-y, Hu Y, Liang W-h, O u C-q, He J-x, et al. Clinical characteristics of 2019 novel corona virus infection in China.doi: 2020:2020.02.06.20020974 